\title{
Resources or Power? Implications of Social Networks on Compensation and Firm Performance
}

\section{Citation}

Horton, Joanne, Yuval Millo, and George Serafeim. "Resources or Power? Implications of Social Networks on Compensation and Firm Performance." Journal of Business Finance \& Accounting 39, nos. 3-4 (April-May 2012).

\section{Published Version}

http://onlinelibrary.wiley.com/doi/10.1111/j.1468-5957.2011.02276.x/abstract

\section{Permanent link}

http://nrs.harvard.edu/urn-3:HUL.InstRepos:9932099

\section{Terms of Use}

This article was downloaded from Harvard University's DASH repository, and is made available under the terms and conditions applicable to Open Access Policy Articles, as set forth at http:// nrs.harvard.edu/urn-3:HUL.InstRepos:dash.current.terms-of-use\#OAP

\section{Share Your Story}

The Harvard community has made this article openly available.

Please share how this access benefits you. Submit a story.

Accessibility 


\title{
Resources or Power? Implications of Social Networks on Compensation and Firm Performance
}

\author{
Joanne Horton*, Yuval Millo ${ }^{\square}$ and George Serafeim ${ }^{\S}$
}

\begin{abstract}
Using a sample of 4,278 listed UK firms, we construct a social network of directorshipinterlocks that comprises 31,495 directors. We use social capital theory and techniques developed in social network analysis to measure a director's connectedness and investigate whether this connectedness is associated with their compensation level and their firms overall performance. We find connectedness is positively associated with compensation and with the firm's future performance. The results do not support the view that executive and outside directors use their connections to rent extract. Rather the company compensates these individuals for the resources these better connections provide to the firm.
\end{abstract}

JEL Classification: G30, G32, J33, L22, M41.

Keywords: corporate governance, compensation, board of directors, social networks, corporate performance

\footnotetext{
*University of Exeter Business School, email: j.horton@exeter.ac.uk London School of Economics, email: y.millo@lse.ac.uk

${ }^{\S}$ Harvard Business School, email: gserafeim@hbs.edu We are grateful to Daniel Ferreira, Fabrizio Ferri, Maria Loumioti, Yao Lu, Mark Mizruchi, Martin Walker, James Westphal and seminar participants at University of Haifa, University of Michigan, University of Essex and the Corporate Governance symposium of European Financial Management Association at University of Cambridge for their insightful comments. We are solely responsible for any errors.
}

Address for correspondence: Joanne Horton, University of Exeter Business School, Streatham Court, Rennes Drive, Exeter, EX4 4PU, email: j.horton@exeter.ac.uk 


\section{Introduction}

Since 2001, there has been increased attention by the media, politicians, and academics on what appears to be overly generous levels of executive compensation (Bebchuk and Fried, 2004). One area of research focuses on whether an executive's social network, and in particular those of chief executive officers (CEOs), are associated with generous compensation packages (Larker et al., 2005; Barnea and Guedj, 2007; Brown et al., 2008; Hwang and Kim, 2009). This prior literature mainly investigates the implications of director ties on the firm's corporate governance, focusing on the potential costs of connections by identifying specific ties between certain individuals that are considered more likely to create agency problems for the firm. But are executive's and outsider director's connections in general always costly for a firm or are there benefits to such ties? The social capital literature suggests that connections do have potential benefits as they create social networks and these networks facilitate access to a broader source of information at a lower cost, and improve its quality, relevance and timeliness (Adler and Kwon, 2002). For example, Useem (1984) noted directorinterlocks enable managers to achieve an optimal 'business scan' of the latest business practices and overall business environment.

Using this initial insight we examine whether the connectedness of executives and outside directors in general provides their respective firms with informational resources or merely provides the individuals with 'managerial power' which they can wield against their firm for their own personal gain. This paper therefore distinguishes itself from others in the literature as we do not take a purely monitoring stance to the issue of connectedness by only focusing on ties between specific individuals. Rather we 
investigate the potential value of a director's overall connectedness-which is generated through their position in the UK network of interlocking corporate directorships — from both an individual and firm perspective. Specifically, we investigate a) whether 'better' connected executives and outside directors are remunerated for their connectedness and b) whether the aggregate connectedness of these individuals provides useful resources to the firm and thereby improves the firm's future performance.

To examine how an executive's or outside director's connections relates to their compensation level and, collectively, to their firm's overall performance, we use social capital theory (Burt, 2005). Social capital theory has developed specific theoretical mechanisms and measures that explain how an individual's level (or collectively on a firm level) of connectedness contributes to their access to information, ability to coordinate actions, and efficacy as a monitoring agent. Focusing on director interlocks, we construct various measures of connectedness using techniques developed in social network analysis (SNA). Our findings indicate that the better an executive's or outside director's connectedness, the higher her compensation. This finding suggests that either the executives and outside directors are rewarded for providing valuable resources to their firms (via their connections), or are rewarded with "managerial power" provided by their connections, which creates opportunities to extract economic rents in the form of "pay-without-performance" (Bebchuk and Fried, 2004).

To distinguish between these two explanations, we investigate the relation between the connectedness of the firm, as a whole created through the collective ties of its board members, and the firm's future performance. We find that the firm's executive 
and outsider director's aggregate connectedness is positively associated with the firm's future performance. These findings suggest that the executives and outside directors are not only rewarded for the resources their connections bring to the firm, but also that these aggregate resources are associated with superior firm performance. All the findings hold when we include several control variables to proxy for the executives' and outside directors' individual 'human capital'. This is especially important since the concept of social capital ('connectedness') and human capital have clear parallels, although they are not identical.

Although we only focus on observable (formal) ties the social capital literature does suggest that social (informal) ties and formal ties such as interlocking board directorships typically complement each other (Hwang and Kim, 2009) and frequently amplify the effects of different types of ties. Informal social ties such as the ones based on club memberships or membership of philanthropic organizations are regarded as venues where new-comer board members can be introduced to norms and values of corporate boards. Westphal et al. (2006) suggest that ties based on interlocking board memberships have effects similar to informal social ties. These interlocking directorships, in addition to being assets in their own right, reflect in the corporate realm, the directors' existing social ties.

It is important to note that, although a director (and collectively a firm) may be able to choose who they are directly connected to, the actual network position resulting from these connections e.g. 'connectedness' is dependent not only on the individual's director connections, but also on who their connections are also connected to. Thus an individual cannot directly have control over their connectedness, but can only increase 
the probability of gaining a desirable network position. ${ }^{1}$ Furthermore, we assume that the market for directors is not a single market, but a collection of partially overlapping markets. Some of the companies, typically in the same industries, compete for the same candidates, but, as whole, the pool of directors is not universal. Therefore, there is not a single point of equilibrium and there is not a single price (compensation) that would clear the market. ${ }^{2}$ Hence, different boards would be looking at different network positions in accordance to which they offer compensation. Also, since the network is composed of partially-overlapping markets, no single board is fully aware of the entire network. We do expect boards to have knowledge of their 'neighbouring' boards, that is, boards with which they share directors or other boards in the same industry. However, better-connected directors are likely to be more visible to the board. Thus, although boards may not be aware of the entire network, public visibility may serve as a proxy for high levels of connectedness.

Our paper makes a number of contributions to the literature. First we provide empirical evidence, for the first time to the best of our knowledge, that the betterconnected an executive or outside director is the greater the benefits to the firm. That is better-connected firms generate superior future performance. Moreover, the firms appear to acknowledge the value of these resources and compensate the individuals for them. Unlike previous studies on compensation and individual ties we are able to infer

\footnotetext{
${ }^{1}$ Social capital is 'located' not in individuals but in their relations with other individuals (Adler and Kwon, 2002). No one individual has exclusive ownership rights to social capital. If you or your partner in the relationship withdraws, the connection dissolves with whatever social capital is contained (Burt, 1992, p.58).

${ }^{2}$ For example, company A may see directors 1,2 and 3 as potential candidates for a director's position. Company B may see directors 3,4 , and 5 as candidates. There is competition between A and B over the pay offered to director 3 , but not over the other directors they consider.
} 
that connectedness is beneficial to a firm and does not necessarily result in managerial power for the individual.

Second, we use the entire population of UK listed firms to construct a network, and we rely on social capital theory to identify which executives and outside directors have the most valuable network resources e.g. who is 'better' connected. By employing social capital theory and using measures from social network analysis, our paper bridges multiple disciplines of research and introduces social ties in general as a new determinant of compensation and firm performance. Thus, we present social network analysis as a useful tool that researchers can use to examine social connections in large scale analysis.

The paper is organized as follows. In section 2 we outline the theory of social capital and describe the social network variables we use in this study. In section 3 we discuss the prior literature and present our hypotheses. Section 4 presents our sample and describes our research design. Section 5 presents the results and several sensitivity tests. Section 6 concludes.

\section{Social capital and social network measures}

Social capital is a concept that has attracted the attention of scholars who seek to explain how individuals mobilize their resources through relationships with others (Adler and Kwon, 2002; for a review see Burt, 2001). The concept is based on the notion that the actions of individuals are greatly facilitated by their membership in social networks. Therefore, social capital can help explain the differential success of individuals and firms in their competitive environments (Adler and Kwon, 2002). As Burt (2000) notes, 
social capital is a metaphor for advantage: people who do better in business are betterconnected in one way or another. For example, research shows that social ties help individuals (firms) gain access to information about job opportunities (potential employees) (Burt, 1992; Fernandez et al., 2000), new innovations (Burt, 1987), and provide a finer grained information set (Uzzi, 1997). Although research shows that social capital plays a central role in determining individual set of opportunities, human capital is also related to this process. Human capital refers to the skills and abilities that an individual possess. For example, degree from a leading university may help a person secure a desirable job. However, once in that job, the person would benefit from the connections the job brings with it. In other words, human capital is converted, at least in part, into social capital. This is consistent with the saying 'it is not what you know, but who you know'. Moreover, such 'conversion' is also possible in the opposite direction (e.g. a person can now apply for an even better job, building on the knowledge they obtained in a previous job). We are aware that social and human capital is deeply intertwined in people's biographical history. However, by focusing on the social networks in which people are embedded at given points in time, we capture the social capital manifestation of both human and social dimensions.

In essence networks are simply information channels, they do not replace information so much as they affect the flow of information and what people or firms can do with it (Burt, 2000). Network participants are not simultaneously aware of the information within the network; communication takes time so the connections between individuals affect who knows what and when. Even if the information is of a high quality, and eventually reaches everyone, the fact that diffusion takes time means that 
individuals with greater social capital are informed early or more broadly and thus have an advantage.

To examine the relevance of social capital theory to compensation and firm performance, we construct a complete interlocking-directorship network that includes not only the direct ties between one executive or outside director and another, but also the indirect ties, those that are generated by a friend of a friend. In this network we draw on social capital theory to determine which connections are "better". We measure two forms of connectedness: closeness centrality which we refer to as "closeness", and aggregate dyadic constraint which we refer to as "brokerage position". In the Appendix we provide a detailed description of how these measures are calculated.

Closeness captures the centrality of the executive or outside director and reflects how near that individual is to all others in the social network. It is defined as the inverse of the shortest path between an individual and all other individuals reachable from it, and measures how close an actor is to all other actors or how central the actor is in the network, after taking into account the centrality of all the other actors. Closeness therefore refers to how efficiently and effectively the individual can communicate with others by either communicating directly or through intermediaries. Taking into account the size of the network, a director with high closeness can quickly transmit and receive information. The shorter the social distance of an individual from others in the network, the higher the quality of information available to that individual: information is going to pass through fewer intermediaries and therefore arrive sooner and be more accurate and detailed. This is particularly important since information quality deteriorates as it moves from one person to the next in a chain of intermediaries. Such an individual can 
access resources more easily, monitor the information flow more effectively, and have a better view of the activity in the network (Freeman, 1980). Closeness is a holistic measure, as it incorporates the aggregate impact of the entire network on the potential strengths and weaknesses embedded in each of the directors' positions.

Our second measure of connectedness is dyadic constraint ('brokerage position'). It quantifies the degree to which the executive or outside director can serve as an effective broker in a network. The lower the executive's dyadic constraint, within her network of connections, the more likely she is to serve effectively as a broker. Thus, a good brokerage position is negatively related to the dyadic constraint. Burt (1992) developed dyadic constraint by building on Granovetter $(1973,1974)$ studies, which are based on the idea that a person can benefit from serving as a link between two or more otherwise disconnected or loosely connected groups in a network. Burt (2005) labels such positions as "structural holes" and suggests that individuals who bridge these holes are in a brokerage position, have access to a wider diversity of information, early access to that information, and more control over information diffusion. On the contrary those individuals with a constrained network position (i.e. no structural holes, where everyone is highly interconnected) have redundant ties, which lowers the potential efficacy of those ties (Burt, 2005). For example, if director A is interlocked with director B and director $\mathrm{C}$, then that connection would be less effective for director A if directors $B$ and $C$ are also interlocked, because $A$ is more likely to receive similar information from both B and C. In addition, redundancy in an individual's connections can also constrain his or her actions, because information on such actions flows in paths that are 
not independent of the person's direct influence (e.g. B and C can exchange information about $A)$.

These two measures depict different dimensions of an individual's connectedness. While closeness measures how accessible information is to the individual, brokerage position measures to what degree that information gives her relative advantage over her network neighbours. Overall these measures capture the idea that being better-connected is not about how many people an individual is directly connected to but more about the quality of those connections e.g. who her connections are connected too.

All the informational advantages of connectedness discussed above can also be applied to the firm level. Certainly one can argue that a firm establishes connections through their inter-connected directors. In other words the network position of a firm's individual directors collectively yields a network position for the firm. Or alternatively, the sum of the individuals' social capital represents the stock of social capital of an organization (Burt, 2005). We therefore measure the closeness (brokerage) position of each firm by aggregating the closeness (brokerage) for each director within the firm.

Although one cannot choose a specific network position, a director can increase the likelihood of a better position in terms of closeness by serving on a board where there are already highly visible directors, given the argument above about visibility and connectedness. To increase the likelihood of a better position in terms of brokerage, a director would choose to serve on more than one board of a company that do not share directors with one another or are in different industries. In so doing, the director would 
increase the chance that by sitting on these boards, he or she would connect previously unconnected areas of the network and thus be in a beneficial brokerage position.

\section{Prior literature and hypotheses}

Because executives and outside directors perform different roles within an organization, it is possible that "connectedness" might have different resource benefits and for this reason will be valued very differently by the firm. This is especially important to consider given the variation of outside director compensation within and across firms here in the $\mathrm{UK}^{3}$ Hence, we present the corresponding literature and hypothesis separately for executive and outside directors.

\subsection{CEOs and other executive officers}

There are currently two views regarding corporate executive pay. One view argues that CEOs' pay follows a well-executed pay-for-performance model (Kay and Van Putten, 2007). The second view suggests that rising executive pay is unrelated to firm performance (Bebchuk and Fried, 2004). These authors argue that executive officers can exert power and influence the decision control function of outside directors in relation to their compensation. According to this power hypothesis, the more power executives exert, the higher the compensation they receive and the more they expropriate wealth from shareholders (Bebchuk and Fried, 2004).

Most of the prior literature examines CEO compensation under a variety of corporate governance structures. The results suggest that firms with weaker governance structures pay their CEOs more (Conyon and Peck, 1998; Core et al.,

\footnotetext{
${ }^{3}$ In the UK there is no maximum threshold for outside director pay. It is very common for directors within a firm to receive different levels of pay. Whilst in the US a fixed fee for outside directorships is very common.
} 
1999). These authors find that CEO compensation is higher when the board is larger; the proportion of outside directors appointed during the CEO tenure increases; and when the board includes CEO interlocking directorships (Hallock, 1997).

Recent work has investigated whether CEOs' social connections are associated with large compensation packages. For example, Larker et al. (2005) find that CEOs are able to extract economic rents when they have links with directors who serve on the board's compensation committee. Main et al. (1995) find that compensation committees whose chairs are appointed after the CEO takes office tend to award higher CEO compensation. Barnea and Guedj (2007) find that firms whose directors have high centrality tend to award their CEOs with higher compensation, although the compensation is less sensitive to firm performance. Hwang and Kim (2009) find that socially dependent boards in which the outside directors have social ties to the CEO offer higher pay levels to their CEOs. Brown et al. (2008) find that the social ties CEOs form over their corporate careers are positively related to their compensation and inversely related to pay-performance sensitivity. All these results suggest that the connectedness of executives has important implications for the efficacy of corporate governance.

If the executive's remuneration is efficiently priced and connections provide the executive with resources that enable her to be a better decision manager, then the more valuable these resources are to the firm and the higher will be her compensation. Alternatively, if executives' connections provide them with managerial power, then executives might be able to extract economic rent by influencing the board and negotiating a more favorable remuneration package. Both scenarios suggest that 
executives who have high levels of closeness and a better brokerage position earn higher levels of compensation. Thus, our first hypothesis is:

$H_{1}$ : An executive officer's compensation level is positively associated with her closeness and brokerage position.

\subsection{Outside directors}

From a corporate governance perspective, outside directors and interlocking directorships perform two functions (Adams and Ferreira, 2007). First, boards use outside directors to enhance the monitoring of management on behalf of the shareholders (Fama and Jensen, 1983), and therefore reduce agency costs and improve a firm's performance (Fama, 1980; Zahra and Pearce, 1989). Second, outside directors provide resources to the firm (Johnson et al., 1996). For example, board members can serve as 'boundary spanners' (Zahra and Pearce, 1989) who provide access to communication channels with the external environment (Pfeffer and Salancik, 1978). Such board members provide their firm with access to new information (Allen, 1974). These resources can, in turn, help reduce dependencies between the firm and external contingencies (Pfeffer and Salancik, 1978), enhance organizational legitimacy (Zahra and Pearce, 1989), reduce uncertainty (Pfeffer, 1972), and lower transaction costs (Williamson, 1984). Thus, these resources impact firm decision making (Mizruchi, 1996) and improve a company's performance and solvency (Mizruchi and Stearns, 1988).

Given these findings, social capital theory provides an ideal framework for examining what determines a firm's demand for outside directors, and ultimately, the level of their compensation. If outside directors can use their connections to become 
better monitors, then the better the monitoring an outside director provides, the higher is her compensation. Prior research finds that outside directors who hold a more central position in their network of inter-board connections and who show a high brokerage position provide legitimacy, which improves the status of the firm (Davis and Greve, 1997); links the firm to other important entities (Hillman et al., 2001); facilitates access to outside financing (Mizruchi and Stearns, 1988; Johnson et al., 1996); helps in strategic decision making (Lorsch and Maclver, 1989); and provides information, expertise, and advice (Westphal, 1999).

Whether or not outside directors with high levels of closeness and brokerage position are more capable monitors is not clear. Individuals in such positions are likely to have an informational advantage over others, and are more likely to be experienced and highly reputable. Therefore, if they utilize their information advantages and if they are willing to risk their reputations, then they might provide effective monitoring of the firm's executive layer. However, by occupying central locations in their social networks, it might be difficult for them to serve as effective monitors of others to whom they are either directly or in some other way very closely connected (Barnea and Guedj, 2007; Larker et al., 2005). As Powell and Smith-Doerr (1997) note "... the ties that bind may also be the ties that blind". Alternatively, by having more connections, outside directors might become even more independent because they are less reliant on any single firm for their compensation and social connections. These connections can motivate them to be more independent and better capable of, for example, raising an independent voice at board meetings. Thus, such outside directors can serve as more effective monitors. 
Even if the connections of outside directors enable them to become better monitors, this better monitoring might not lead directly to higher levels of compensation. Fama and Jensen (1983) argue that many outside directors are either executives or important decision agents in other organizations, and that they use their outside directorships to signal their reputation as experts in decision control. Consequently they are much more focused on the reputational effects than on salary. Fama and Jensen (1983) suggest that such signals are only credible when the direct payments to outside directors are small. Under this scenario, a negative relation would exist between outside directors' compensation and their closeness and brokerage position. Therefore, we write a non-directional hypothesis, as follows:

$\mathrm{H}_{2}$ : An outside director's compensation level is associated with her closeness and brokerage position.

\subsection{A firm's connectedness and future profitability}

The existing literature suggests that if a director's connectedness generates useful resources then collectively these resources will be associated to the firm's profitability. For example, Haunschild and Beckman (1998) find that a director's connectedness provides information which influences the strategic choices of firms. A firm whose individuals are more central to the network will have more opportunities to access all network information, and access it in a timelier manner. For example the firm will have better access to the latest business practices and have a better view of the overall business environment. Barr (2000) finds that social capital in the form of social relationships embedded within bounded institutional or diffused community structures influences economic performance. This is partly because such networks facilitate the 
flow of technical information and knowledge that helps reduce economic transitions costs as well as serve as crucial input in the production process. Fernandez et al. (2000) measured the 'instrumental' value to a firm of its employees' social network. Within the context of a large U.S. customer service call center, the authors find that the firm's social capital investments (reflected in the $\$ 250$ referral bonus given to current employees for each successful hire who lasted through a specified time period) resulted in gathering a 'net benefit' through the firm's acquiring a 'richer pool' of candidates.

Likewise, if connectedness of an outside director enables her to increase her efficacy as a monitoring agent then the firm's agency costs will also decrease and potentially the firm's performance will improve. Consequently we would expect to see a positive association between a firm's connectedness and the firm's current and future performance. Unless the profitability or valuation of the company already reflects the benefits coming from the resources provided by its executives and outside directors, then the future performance will be unrelated to these services, after controlling for current performance.

In addition, given our definition of rent extraction as a situation whereby the director's compensation is positively correlated with their network measures, but not with future performance of the company (controlling for current performance). Our regression model focuses on this definition and tests if these conditions exist. If betterconnected executives and outside directors receive higher compensation partly because their connections provide them with opportunities to extract economic rents, then the association between the firm's connectedness and its future performance will 
be negative. If this is not the case then we can rule out rent extraction. Thus, our third hypothesis is:

$H_{3}$ : The firm's closeness or brokerage position is associated with its future performance.

\section{Sample and research design}

\subsection{Sample}

Our sample consists of nearly all the UK companies on the London Stock Exchange (LSE) that are listed on either the Main or the Alternative Investment Market (AIM) between 2000 and 2007. We obtain executive and outside director's compensation data mainly from Hemscott, with other completions from BoardEx, and all stock market and accounting data from DataStream and Worldscope.

To calculate the network measures for each individual, we construct a complete interlocking-director network that comprises 4,278 firms, 31,495 directors ${ }^{4}$, and 111,114 directorship-years. ${ }^{5}$ After excluding observations with missing or zero compensation, the final sample for the econometric analysis contains 3,332 firms, 21,970 directors, and 76,241 directorship-years (see Table 1 ). ${ }^{6}$ The firms are from a wide range of industries and vary significantly in terms of size; firms range from a market value of $£ 100$ million to a market value of $£ 158$ billion.

\section{[Insert Table 1]}

We obtain compensation data for each executive and outside director from Hemscott. Hemscott calculates total compensation as the sum of salary, bonus, stock options, pension benefits, and other benefits. Because Hemscott excludes

\footnotetext{
${ }^{4}$ Director in this paper is used as a collective term to describe both executive officers and outside directors.

${ }^{5}$ All 31,495 directors are connected to each other (directly or indirectly), in one or more of the years.

${ }^{6}$ See appendix for details about the calculation of network measures.
} 
compensation from long-term incentive plans (LTIPS) that are widely used in the UK instead of stock option schemes, we obtain data on LTIPs from BoardEx. However, after matching the two databases we are unable to obtain LTIPs data for about $30 \%$ of our Hemscott sample (mainly AIM firms). Therefore, in our primary analysis we use the compensation data from Hemscott without LTIPs. However, we report results also using the smaller sample with LTIP data.

There are two more reasons why excluding LTIPs from the primary analysis might be preferable. First, because the amount of compensation that is ultimately received from LTIPs is uncertain at the time the compensation is agreed and the LTIPS' valuation is not straightforward. Second, because outside directors are not usually included in LTIPs. This lacuna impairs the comparability in compensation across director categories. We would like to maintain this comparability, since it makes it possible for us to infer whether social networks have a differential impact on compensation.

Table 1 provides the statistics at the firm level. The average firm closeness is 0.087 with a standard deviation of 0.049 , and average firm brokerage (dyadic constraint) is 0.662 with a standard deviation of 0.226 . We find that both closeness and brokerage exhibit high levels of persistence, with first-order autocorrelations of 0.7 and 0.8 , respectively. The average firm size is $£ 953$ million with a standard deviation of £6146 million. The average stock return is $16 \%$ and the average sales growth is $12 \%$. In contrast, the average return on assets (ROA) is negative $(-4.0 \%)$, although $65 \%$ of the observations do have a positive ROA. Average market-to-book ratio (MTB) is 2.51 and the median board has seven members. 
Table 2 Panels $\mathrm{A}$ and $\mathrm{B}$, provide the statistics by category of director. ${ }^{7}$ CEOs have the highest average compensation of $£ 447,000$ (with LTIPS, this total rises to $£ 577,000$ ), followed by other senior executives and CFOs (see Panel A). ${ }^{8}$ Chairmen of boards have a much lower average compensation of $£ 102,000$ (with LTIPs, £88,000). Other outside directors have an average compensation of $£ 36,000$ (with LTIPs, $£ 32,000$ ) (See Panel A). The average closeness for CEOs and CFOs is 0.08 and 0.09 respectively with a standard deviation of 0.05 and 0.047 . The average CEO brokerage (one minus the dyadic constraint) is 0.65 with a standard deviation of 0.21 . Again we find that both closeness and brokerage exhibit high levels of persistence, with first-order autocorrelations of 0.8 and 0.9 , respectively. Outside directors have moderately higher levels of closeness and brokerage position relative to executive officers with an average closeness of 0.1 and brokerage of 0.77 (see Panel B). The median CEO tenure is approximately seven years, two years longer than for both CFO and other outside directors. In addition the CEO's are more likely to have attended a top school, such as Oxford or Cambridge etc. and obtained an MBA compared to other directors.

From the directorships in our data set, $15 \%$ also include a position on the nomination committee, $38 \%$ on the remuneration committee, and $45 \%$ on the audit committee. Also individuals who sit on three or more boards (busy directors) hold $17 \%$ percent of the directorships. Men hold $95 \%$ of directorships.

\section{[Insert Table 2]}

\footnotetext{
${ }^{7}$ We note that although we obtain a director's job classification from Hemscott, that database is not complete, so at times it is difficult to unambiguously classify a director. For example, for some companies the chairperson might also be the CEO of the firm. Although this is not the case (>95\%) for the majority of UK companies, we might be misclassifying some directors to other categories. However, we do not expect this misclassification to bias our results in one direction, but rather to add noise, reducing the power of the tests. We classify any directors as CEOs if they are both a CEO and a chairperson.

${ }^{8}$ The average compensation with LTIPs is lower because the majority of data points are missing for the executive officers that tend to receive the highest compensation.
} 


\subsection{Research design}

To test whether there is an association between an executive's and an outside director's compensation and her connectedness, we use the following model:

$$
\begin{aligned}
\text { Comp }_{i j t}= & \alpha+\beta_{1} \text { Social Network Measure }_{i t}+\beta_{2} \text { Gender }_{i}+\beta_{3} \text { Busy }_{i t} \\
& +\beta_{4} \text { HumanCapital Measures }_{i t}+\beta_{5} \text { Job }_{i j t}+\beta_{6} \text { Committee }_{i j t} \\
& +\beta_{7} \text { Firm Characteristics }_{j t}+\beta_{8} \text { Index }_{j t}+\sum_{I=1}^{44} \gamma_{I} \text { Industry }_{j t}+\sum_{t=2000}^{2007} \gamma_{t} \text { Time }_{i j t}+\varepsilon_{i j t}
\end{aligned}
$$

Where Comp $p_{i j t}$ is the natural $\log$ of the total compensation for director $i$, in firm $j$ in year $t$ and the Social Network Measure ${ }_{i t}$ which is either closeness or brokerage position for director $i$ in year $t$.

We include several control variables to capture possible economic determinants of directors' pay. We control for the gender of the director and for whether the director is a 'busy' director (Fich and Shivdasani, 2006). Busy directors might be better compensated because of their high reputation or less well compensated because they have less time to spend on each firm. By including this variable we also alleviate any concerns that our variables capture the effect of being a busy board member. We also include a number of controls in an attempt to capture the directors' human capital. We employ both informal (experience) and formal (education) human capital variables (Cressy, 1996). ${ }^{9}$ We include the tenure and age of the director, since directors with higher tenure and older directors are more experienced and knowledgeable, and thus receive a relatively higher compensation (Murphy, 1999). ${ }^{10}$ The formal human capital

\footnotetext{
${ }^{9}$ The nationality of the directors is not included as a variable given there is no theory to suggest, both from a human capital perspective nor a network creating perspective, that a certain nationality is better or worse than another.

${ }^{10}$ We note that by controlling for tenure, we are essentially biasing against our predictions, since the tenure of a director partly reflects her social status.
} 
variables relate to the director's educational background. In particular we control for whether the director attended a top school. ${ }^{11}$ We also control for the level of education achieved by the director, for example whether the director has a $\mathrm{PhD}$, or if they have obtained an MBA and/or have any other professional qualifications such as the chartered accountant certificate. We use the general job descriptions in Hemscott to determine job-role fixed effects, and indicator variables that show whether an individual sits on the nomination, remuneration, or audit committees.

In addition to these director-level characteristics variables we also, as in previous research, control for firm-level characteristics. We use the size of the firm, calculated as the logarithm of the market value of equity, which we expect to be positively correlated with compensation, since larger firms are more complex and therefore require more skilled executives (Gabaix and Landier, 2008). We measure the firm's profitability and performance by using the market-to-book (MTB) ratio, which serves as our proxy for a firm's growth opportunities, and we expect it to be positively related to compensation (Smith and Watts, 1992); the return on assets (ROA); the one-year total stock price return; and the one-year sales growth (Core et al., 2008). To capture any asymmetric relations, we inter-act the performance controls, with indicator variables that reflect whether the performance measures are positive or negative. We also include the number of board members, since Yermack (1996) finds that larger boards are more entrenched and thus are more likely to approve higher compensation packages. We control for the firm's London Stock Exchange Index membership (Index $x_{j t}$ ), industry

\footnotetext{
${ }^{11}$ We define top schools as Oxford, Cambridge, Harvard and the top London based universities (especially given their proximity to the UK business community) such as London School of Economics, London Business School, Imperial College and University College London (UCL).
} 
membership, ${ }^{12}$ and year fixed effects. We cluster standard errors at the director level to mitigate serial and cross-directorship correlation within a director.

Given that CEO compensation has attracted considerable attention relative to other directors, we consider CEOs separately. Likewise we also consider CFOs separately as we believe there is relatively more homogeneity in their job role than for other executives, thus reducing any potential noise.

To test whether there is an association between the firm's connectedness and the firm's subsequent performance, we run the following model:

$$
\begin{aligned}
\text { Performance }_{j t, t+2}= & \alpha+\beta_{1} \text { Firm' s Social Network Measure }_{j t-1}+\beta_{2} \text { Performance }_{j t-1} \\
& +\beta_{3} \text { ooutside }_{j t}+\beta_{4} \% \text { Busy }_{j t}+\beta_{5} \text { Human Capital Measures }_{j t} \\
& +\sum_{I=1}^{44} \gamma_{I} \text { Industry }_{j t}+\sum_{t=2000}^{2007} \gamma_{t} \text { Time }_{i j t}+\varepsilon_{j t}
\end{aligned}
$$

We derive the firm's social network measure by aggregating the firm's individual director's connectedness. We also assess the sensitivity of our results to this method and construct the average director's connectedness to obtain firm level connectedness. The dependent variable Performance $j t, t+2$, is the firm performance averaged over the subsequent one-, two- and three-year period. ${ }^{13}$ We use three different measures of firm performance: total stock return, market-to-book and return on assets (Core et al., 1999). We also include as an independent variable the lag firm performance variable Performance $_{j t-1}$, to control for the endogeneity of the firm's selection process, i.e., that the better-performing firms choose better directors who are better-connected and as a

\footnotetext{
${ }^{12}$ We use five LSE index membership classifications: FTSE 100, FTSE250, FTSE350, core AIM and Fledging AIM, and 44 industry classifications.

${ }^{13}$ This approach is consistent with the method used in other studies (e.g., Core, Holthausen, and Larcker, 1999; Hwang and Kim, 2009).
} 
result provide relatively higher quality service. We therefore control for historical factors that might be the cause for current differences in performance (Wooldridge, 2001).

We do not expect stock returns to be serially correlated, although we expect MTB and $R O A$, to exhibit high persistence over time. In model 2 we also use controls for

other board characteristics that prior studies suggest are related to a firm's performance. We include controls for board size (Yermack, 1996), the percentage of independent directors sitting on the board (\%outside) (Klein, 1998), and the percentage of busy directors (\%Busy) (Fich and Shivdasani, 2006). In addition we also include a number of variables to capture the director's main human capital attributes: experience and educational attainment. We therefore include average tenure of the directors; the proportion of directors within the firm that have been educated at a top school and the proportion of directors that have obtained professional qualifications, e.g. MBA, ACA, ACCA, PhD. We also control for the firm's industry membership and year fixed effects.

\section{Results}

[Insert Table 3]

Table 3 presents the correlation matrices. Panel $\mathrm{A}$ is the correlation matrices for CEOs and other executives and Panel B is the correlation matrices for chairmen and other outside directors. For CEOs (below diagonal), we find that compensation has a strong positive correlation with closeness (0.40) and brokerage position (0.48). For both chairman (below diagonal) and outside directors (above diagonal) we find the compensation has again a positive although weaker correlation with closeness and brokerage. For example the chairman's compensation has a correlation with closeness 
of 0.08 and with brokerage position of 0.15 . For all categories of director compensation, closeness and brokerage are positively associated with firm size, ROA, and MTB. The human capital variables, top school, MBA, professional qualifications are all positively correlated to compensation, closeness and brokerage, although director tenure is weakly related to both measures of connectedness. Busy directors have higher closeness and better brokerage positions.

[Insert Table 4]

Table 4 (Panel A and B) presents the results from our model 1 regression analysis. Panel A reports the results for the executive officers and Panel B reports the results for outside directors. Panel A, columns 1 to 4 present the results for the CEOs. In columns 1 and 3 , closeness exhibits a significant positive association with compensation. An increase of one standard deviation in closeness increases CEO compensation by approximately $£ 20,500$ (with LTIPs, £33,000). Columns 2 and 4 show that the level of brokerage also has a significant positive association with compensation. Compensation has no relation to gender and is negatively associated to how busy the executive is. In unreported results we find compensation increases with tenure and particularly for CEO's, attending Oxford University, or having either an ACA qualification, MBA, or $\mathrm{PhD}$ increases compensation.

Because we control for factors, such as tenure, business, and committee membership, that might also be influenced by networks, the economic effects from network connections can be downward biased. When we test the same relations for CFOs, in columns 5 and 6 our results are nearly identical to those for CEOs. For the remaining executives we find similar results to those of CEOs and CFOs for closeness 
which is positive and significantly associated to compensation. However, it does not appear that other executives are rewarded for their brokerage position, suggesting the firm does not find such a position in other executives useful. The coefficients are statistically significant at the $1 \%$ and $5 \%$ levels, respectively. The results overall provide evidence that firms compensate their executive officers according to their position in the social network and for the reciprocating resources. A move from the $10^{\text {th }}$ percentile to the $90^{\text {th }}$ percentile based on the closeness increases an executive's compensation by approximately $9 \%$.

The results for non-executive directors, reported in Table 4, Panel B, are consistent with the executive results. We note that in this part of our analysis, if an individual is both an executive and an outside director, then we focus only on the compensation received from the outside directorship. For both Chairman (columns 1 to 4) and other outside directors (columns 5 to 8 ) the network measures are positively and significantly associated to compensation. An increase of one standard deviation in closeness increases outside directors' compensation by $6 \%$. A move from the $10^{\text {th }}$ percentile to the $90^{\text {th }}$ percentile based on the brokerage position increases compensation by approximately $10 \%$.

Both male and more experienced outside directors earn higher compensation, but busy directors earn lower compensation. Only Oxford University attendance and a chartered accounting qualification appear to be significantly related to an outside director's compensation level.

All these results suggest that compensation increases with an individual's level of connectedness. This relation could be the result of an efficient contract between the firm 
and the director, or because the director is able to exercise managerial power and extract economic rents. To distinguish between those two explanations we test the relation between the firm's level of connectedness and its future performance. The results of model 2 are reported in Table 5.

\section{[Insert Table 5]}

We find a firm's connectedness is associated to its future performance. Betterconnected firms have better future performance. For instance when the dependent variable is either the firm's average two- or three-year future stock return, the coefficients on the firm's connectedness is 46.90 and 38.12 respectively, significant at the $0.1 \%$ level and $5 \%$ level. An increase of one standard deviation in the firm's connectedness increases the firm's two-year average future stock return by $4 \%$, an estimate that is economically significant. When the stock return is replaced with either MTB or ROA the results are consistent. For example, when the dependent variable is three-year average MTB the magnitude of the coefficient suggests that a one standard deviation increase in the firm's connectedness increases this three-year average MTB by approximately 19 points. An increase of one standard deviation in the firm's connectedness variable increases ROA by approximately 0.22 points. We find that both MTB and ROA exhibit high persistence, with coefficients ranging from 0.53 to 0.56 and from 0.46 to 0.62 respectively on past performance, respectively. In contrast, stock returns indicate no persistence. These results continue to hold when we replace the firm's aggregate connectedness with the firm's average connectedness. Similarly when we measure firm connectedness using brokerage as opposed to closeness our results are almost identical to those reported in Table 5. In other unreported results we find that 
a firm's performance is also positively associated to the proportion of a firm's directors who attended a 'top school'. ${ }^{14}$ However, this association diminishes as the time horizon increases. For example, when the dependent variable is the average one-year stock return the 'top school' coefficient is 17.17 and significant at $0.1 \%$, the coefficient then reduces to 7.20 when we move to an average two-year stock return and reduces again to 3.4 when we move to an average three-year stock return, neither is statistically significant. This suggests that human capital may have a limit in determining a firm's future success suggested by Davidsson and Honig (2003) who find that human capital determines an individual's entrance into a firm however, it does not determine an individual's overall success once in the firm. Similarly, Boxman et al. (1991) find human and social capital interact in producing income, but returns on human capital decrease when there is access to abundant social capital.

\section{Additional Analysis and Sensitivity tests}

\subsubsection{Alternative network measures}

Instead of using the closeness and brokerage (dyadic constraint) to capture a director's connectedness, we investigate two alternative social network measures, betweenness centrality and K-core, which have been used in prior social capital research. Betweenness centrality of an individual $j$ is defined as the ratio of the number of shortest paths connecting two individuals, $i$ and $k$, that pass through individual $j$ and the overall number of shortest paths that connect $i$ and $k$ (Freeman, 1980). This measure is normalized and ranges from zero to one. Similar to the dyadic constraint, betweenness

\footnotetext{
${ }^{14}$ We also included as addition human capital variables MBA, PhD and ACA attainment, however none of these variables were found to be robust across all specifications.
} 
captures how much information flows through a certain director, and thus the degree to which that director can serve as a broker between pairs of other directors. K-core is a particular area of the overall network (a sub-network) in which each director has at least $k$ immediate neighbours. The higher the $k$ of a director, the better-connected are her neighbours. Hence, she has fewer brokerage opportunities, her information is relatively less scarce, and her actions are more constrained (Moody and White, 2003). We divide this measure by the director's degree. The higher the ratio, the less relative advantage the director's information is likely to have. When using these measures all our results remain unchanged.

\subsubsection{LSE compared to AIM}

A potential concern is that firms listed on the LSE main market are very different from the firms on the AIM market. By default, firms on the main market are larger and hence more visible, and subject to stricter governance structures relative to firms on the AIM. When we examine firms within the main market, we find that our results are stronger for

these firms compared to firms listed on the AIM. Therefore, it appears that a director's social network is more important for determining her compensation when her firm is listed on the main market.

\subsubsection{Linear Relation}

In addition to investigating a linear relation between a director's connectedness and her compensation we also investigate the possibility of a curvilinear relation. For example, a director incurs costs to maintain her many connections (Burt, 2005) but at the same time may receive diminishing returns from each incremental connection. Can you be too connected? We therefore include a quadratic measure of connectedness as an 
additional variable, to address these concerns. We find although the quadratic term is negative, consistent with the idea of diminishing returns, it is not significant, nor does its inclusion change the previous results.

\section{Conclusion}

In this paper, we use social network analysis to measure the connectedness of directors within the entire director network. We find that executives' and outside directors' compensation is associated with the characteristics of their social connections. Executive directors, such as CEOs, CFOs, and outside directors, such as chairmen, who have high levels of closeness and better brokerage positions earn higher compensation. We also find evidence that these aggregate connections which generate the firm's connectedness are positively associated with future performance. This finding is inconsistent with managerial power and rent-extraction by executives, and consistent with executives receiving compensation for the resources they bring to a firm. Overall we find on average connections are beneficial to the individual as well as to their firm. Not all connections are bad connections.

A number of caveats apply to this study. First, as in any network study, the social network is incomplete. Although director interlocks have been found to reflect social ties (Hwang and Kim, 2009), we do not capture all possible avenues through which a director can obtain an information advantage such as golf club memberships, religious activities, political affiliations etc. Nevertheless we believe these social or grey ties add noise to our network estimates potentially biasing downwards the network effect we document. Second, whilst we have tried to control for human capital and its potential 
endogeneity with our social capital measures, we cannot completely rule out that higher ability directors have a higher probability of acquiring better network positions. However we can take some comfort from the results of our analysis, that there appears to be diminishing returns from a director's human capital e.g. educational attainment etc. in relation to future firm performance, as opposed to her social capital results. These results are consistent with prior research. Third, as with any study of this kind, there is a possibility of a correlated missing variable driving the results. However we have included numerous control variables which we think are the most likely causes of both director pay and firm performance. 


\section{Appendix}

\section{Calculation of network measures}

Closeness centrality is the inverse of the mean geodesic distance (i.e., the shortest path) between a vertex $v$ and all other vertices reachable from it:

$$
X_{v}=\frac{N-1}{\sum_{w=1}^{N} u(v, w)}
$$

$X$ is the closeness centrality of a vertex $v$ in a network in which $N$ is the number of vertices and $u(v, w)$ is the distance between the given vertex $(v)$ and another vertex $(w)$. Therefore, using the example of a network below $C$ has a closeness centrality of 0.6111 .

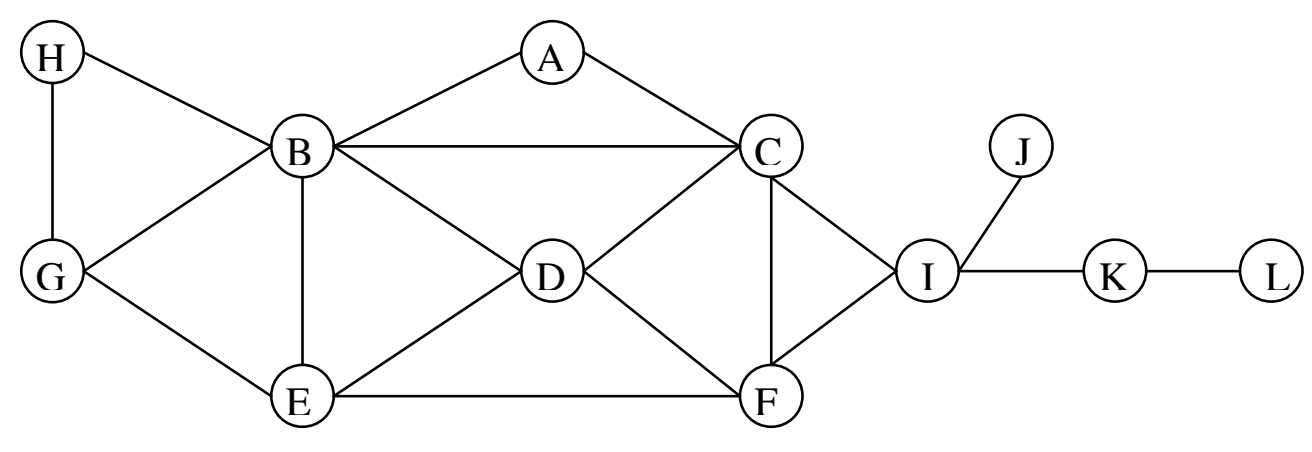

\begin{tabular}{|c|c|c|c|}
\hline Directors & Closeness & Directors & Closeness \\
\hline A & 0.4583 & G & 0.4074 \\
\hline B & 0.5500 & $\mathrm{H}$ & 0.3793 \\
\hline C & 0.6111 & $\mathrm{I}$ & 0.5500 \\
\hline D & 0.5000 & $\mathrm{~J}$ & 0.3667 \\
\hline E & 0.5000 & $\mathrm{~K}$ & 0.3928 \\
\hline F & 0.5500 & $\mathrm{~L}$ & 0.2895 \\
\hline
\end{tabular}

This is calculated as (12-1) divided by the five direct ties to $A, B, D, F$ and I with a distance of one $(1+1+1+1+1)$ plus the indirect ties which take a geodesic distance of two for $C$ to connect to $E, G, H, J$ and $K(2+2+2+2+2)$ plus the geodesic distance of three to connect to $L$. Thus closeness centrality is 11 divided by 18 . In Pajek, the software package we use to calculate the network measures (Batagelj and Mrvar, 
2009), closeness of each individual is weighted by the total number of individuals in the entire network. We only include the single biggest component for each year, but the closeness measure does reflect the fact that there were other components in the network.

"Dyadic Constraint," the brokerage position, is based on Ronald Burt's (1992) concept of structural holes. The simplest structure in which dyadic constraint is expressed is the triad, a fully or partially connected set of three nodes. Structures that are more complex can be decomposed into triads. Hence, the calculation of dyadic constraint is based on breaking down network structures to triads. Below is the breakdown of l's ties, from the example above:

Breakdown of I's ties

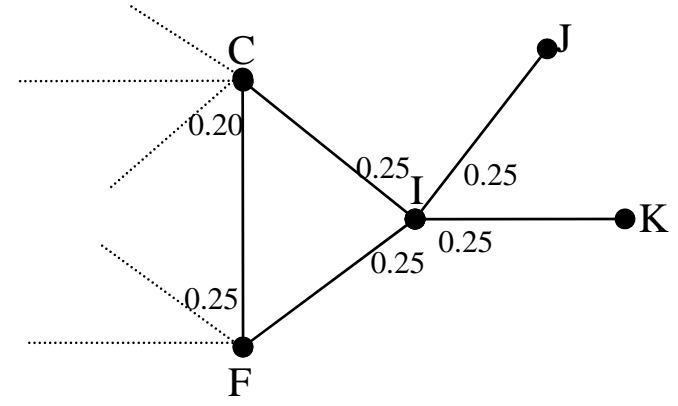

Using Pajek (de Nooy et al., 2005) we calculate the aggregate dyadic constraint using the following dyadic constraint formula (Burt 1992, pp.54-55):

$$
C_{i j}=\left(p_{i j}+\sum_{q} p_{i q} p_{q j}\right)^{2}, \text { for } p \neq i, j
$$

where $p_{i j}$ is the proportion of $i$ 's relations invested in actor $j$. The sum $\sum_{q} p_{i q} p_{q j}$ is the extent of $i$ 's relations invested in actor q's relations, which in turn are invested in actor $j$. The total in parentheses is the proportions of i's relations that are directly or indirectly invested in its connections with actor $j$. We show the calculation of dyadic constraint for node $I$. First, we calculate the value of each of the ties that a node is part of as an inverse of its number of connections. Node $I$ in the example above has four ties. Hence, 
each of node I's ties will have a value of $1 / 4, F$ ties will also have a value of $1 / 4$, and $C$ will have a value of $1 / 5$ and both $J$ and $K$ ties will have a value one and $1 / 2$ respectively. Second, using the values of these ties, we calculate the constraint that each of the ties imposes on $I$. Since $I$ is part of the triad $C-F-I$, the tie $F-C$ is limiting the value that $I$ can have had from having separate connections with $C$ and $F$. Therefore, the constraint that each of these nodes imposes on I includes not only the node's connection with I, but also the connection between them. The constraint on I attached to her tie with $F$ is equal to the square of the following sum: 0.25 (l's investment in $F$ ), plus $0.25 \times 0.2$ (l's tie to $C$ time's $C$ tie to $F$ ), which equals 0.09 . Similarly, the constraint on $I$ attached to her tie with $C$ is equal to 0.0976 (i.e., [0.25 $+(0.25 \times 0.25)]^{2}$. The constraint with both $J$ and $K$ is just the squares of the proportional strengths of these ties $(0.0625)$, because there are no indirect ties from $I$ to either $J$ or $K$. Once we have the dyadic constraint on all ties of $I$, we add them to obtain the aggregate constraint. Therefore, the aggregate constraint for $I$ is 0.3126 (i.e. $0.09+0.0976+0.0625+0.0625$ ). Based on the example above $I$ is the least constrained director, and therefore holds the 'best' brokerage position within the entire network. I connects $J, K$ and $L$ to the other group containing $C, F, D$ etc. From the example above $A$ to $F$ all tend to have similar information. Indeed, all the ties to $D$ are redundant since $D$ can only transmit information provided by $B, C, E$, and $F$, but cannot provide new and different information.

\begin{tabular}{|c|c|c|c|}
\hline Directors & Dyadic Constraint & Directors & Dyadic Constraint \\
\hline A & 0.7003 & G & 0.6427 \\
\hline B & 0.3875 & H & 0.7847 \\
\hline C & 0.4097 & I & 0.3126 \\
\hline D & 0.5137 & J & 1.0000 \\
\hline E & 0.4648 & K & 0.5000 \\
\hline F & 0.4597 & L & 1.0000 \\
\hline
\end{tabular}




\section{References}

Adams, R. and D. Ferreira (2007), 'A Theory of Friendly Boards', Journal of Finance, Vol.62, pp.217-250.

Adler, P.S. and S. Kwon (2002), 'Social capital: Prospects for a New Concept', Academy of Management Review, Vol.27, pp.17-40.

Allen, M.P. (1974), 'The Structure of Inter-organizational Elite Cooptation: Interlocking Corporate Directorates', American Sociological Review, Vol.39, pp.393-406.

Barnea, A. and I. Guedj, (2007), 'CEO Compensation and Director Networks', Unpublished paper, University of Texas at Austin.

Barr, A. (2000), 'Social Capital and Technical Information Flows in the Ghanaian Manufacturing Sector', Oxford Economic Papers, Vol.52, No.3, pp.539-559.

Batagelj V. and A. Mrvar, (2009), Pajek - Program for Large Network Analysis (Version 1.24).

Bebchuk, L. and J. Fried (2004), Pay Without Performance: The Unfulfilled Promise of Executive Compensation (Cambridge, MA: Harvard University Press).

Boxman, E.A.W., P.M. De Grant, and H.D. Flap (1991), 'The Impact of Social and Human Capital on the Income Attainment of Dutch Managers'. Social Networks, Vol.13, pp.51-73.

Brown, R., E. Lee, G. Ning and K. Stathopoulos (2008), 'What are Friends For? CEO Networks, Pay and Corporate Governance', Working paper (Manchester Business School).

Burt, R. (1987), 'Social Contagion and Innovation: Cohesion versus Structural Equivalence', American Journal of Sociology, Vol.92, pp.1287-1335.

Burt, R. (1992), Structural Holes: The Social Structure of Competition (Cambridge MA: Harvard University Press). 
Burt, R. (2000), Structural Holes versus Network Closure as Social Capital. (Pre-print for a chapter in Social Capital: Theory and Research. Edited by Lin, N., Cook, S. and Burt, R. 2001).

Burt, R. (2001) The Social Capital of Structural Holes. (Pre-print of a chapter in New Directions in Economic Sociology. Edited by Guillen, M.F., Collins, R., Enghad, P., and Meyer, M., NY: Russel Sage Foundation).

Burt, R. (2005) Brokerage and Closure: An Introduction to Social Capital (Oxford: Oxford University Press).

Conyon, M. and S. Peck (1998) 'Board Control, Remuneration Committees and Management Compensation', Academy of Management Journal, Vol.41, pp.146-157.

Core, J., R. Holthausen, and D. Larcker (1999) 'Corporate Governance, Chief Executive Officer Compensation, and Firm Performance', Journal of Financial Economics, Vol.51, pp.371- 406.

Core, J., W. Guay and D. Larcker (2008), 'The Power of the Pen and Executive Compensation', Journal of Financial Economics, Vol.88, pp.1-25.

Cressy, R. (1996), 'Are Business Startups Debt-rationed?', The Economic Journal, Vol.106, No.438, pp.253-270.

Davidsson, P. and B. Honig (2003), 'The Role of Social and Human Capital Among Nascent Entrepreneurs', Journal of Business Venturing, Vol.18, No.3, pp.301-331.

Davis, G.F. and H.R. Greve (1997), 'Corporate Elite Networks and Governance changes in the 1980s', American Journal of Sociology, Vol.103, pp.1-37.

de Nooy W., A. Mrvar and V. Batagelj (2005), Exploratory Social Network Analysis with Pajek (Cambridge: Cambridge University Press).

Fama, E. (1980), 'Agency Problems and the Theory of the Firm', Journal of Political Economy, Vol.88, pp.288-307.

Fama, E., M. Jensen (1983), 'Separation of Ownership and Control', Journal of Law and Economics, Vol.26, pp.301-25. 
Fernández, R.M., E.J. Castilla and P. Moore (2000), 'Social Capital at Work: Networks and Employment at a Phone Center', American Journal of Sociology, Vol.105, No.5, pp.1288-1356.

Fich, E. and A. Shivdasani (2006), 'Are Busy Boards Effective Monitors?' Journal of Finance, Vol.61, pp.689-724.

Freeman, L.C. (1980), 'The Gatekeeper, Pair-dependency and Structural Centrality', Quality and Quantity, Vol.14, pp.585-592.

Gabaix, X. and A. Landier (2008), 'Why has CEO Pay Increased So Much?', Quarterly Journal of Economics, Vol.123, pp.49-100.

Granovetter, M. (1973), 'The Strength of Weak Ties', American Journal of Sociology, Vol.78, pp.1360-1380.

Granovetter, M. (1974), Getting a Job: A Study of Contacts and Careers (Cambridge, Mass.: Harvard University Press).

Hallock, K. (1997), 'Reciprocally Interlocking Boards of Directors and Executive Compensation', Journal of Financial and Quantitative Analysis, Vol.32, pp.331-344.

Haunschild, P.R. and C.M. Beckman (1998), 'When do Interlocks Matter?: Alternative Sources of Information and Interlock Influence', Administrative Science Quarterly, Vol.43, pp.815-844.

Hillman, A., G. Keim, and R. Luce (2001), 'Board Composition and Stakeholder Performance: Do Stakeholder Directors Make a Difference?' Business and Society, Vol.40, pp.295-314.

Hwang, B. and S. Kim (2009), 'It Pays to have Friends', Journal of Financial Economics, (forthcoming).

Johnson, J.L., C.M. Daily and A.E. Ellstrand (1996), 'Boards of Directors: A Review and Research Agenda', Journal of Management, Vol.22, pp.409-438.

Kay, I.T. and S. Van Putten (2007), Myths and Realities of Executive Pay (Cambridge University Press). 
Klein, A. (1998), 'Firm Performance and Board Committee Structure', Journal of Law and Economics, Vol.41, pp.275-299.

Larcker, D., S. Richardson, A. Seary, and I. Tuna (2005), 'Back Door Links between Directors and Executive Compensation' Working Paper (Stanford GSB).

Lorsch, J. and E. Maclver (1989), Pawns or Potentates: The Reality of America's Corporate Boards (Cambridge, MA: Harvard Business School Press).

Main, B.G.M., C.A. O'Reilly and J. Wade (1995), 'The CEO, the Board of Directors and Executive Compensation: Economic and Psychological Perspectives', Industrial and Corporate Change, Vol.11, pp.292-332.

Mizruchi, M.S. (1996), 'What do Interlocks do? An Analysis, Critique, and Assessment of Research on Interlocking Directorates', Annual Review of Sociology, Vol.22, pp.271298.

Mizruchi, M. and L. Stearns (1988), 'A Longitudinal Study of the Formation of Interlocking Directorates', Administrative Science Quarterly, Vol.33, pp.194-210.

Moody, J. and D. White (2003), 'Social Cohesion and Embeddedness: A Hierarchical Conception of Social Groups', American Sociological Review, Vol.68, pp.1-25.

Murphy, K. (1999), Executive Compensation (In Orley A. and D. Card, editors, Handbook of Labor Economics 3b. New York and Oxford, Elsevier Science North Holland, pp.2485-2563).

Pfeffer, J. and G. Salancik, (1978), The External Control of Organizations: A ResourceDependence Perspective (New York: Harper \& Row).

Pfeffer, J. (1972), 'Size and Composition of Corporate Boards of Directors: The Organization and its Environment', Administrative Science Quarterly, Vol.17, pp.218228.

Powell, W.W. and L. Smith-Doerr (1997), Networks and Economic Life (In N.J. Smelser and R. Swedberg (Ed.), The handbook of economic sociology. Princeton: Princeton University Press, pp.368-402). 
Smith, C. and Watts, R. (1992), 'The Investment Opportunity Set and Corporate Financing, Dividend and Compensation Policies', Journal of Financial Economics, Vol.32, pp.263-292.

Westphal, J.D., S. Boivie, and D.H.M. Chng (2006), 'The Strategic Impetus for Social Network Ties: Reconstituting Broken CEO Friendship Ties' Strategic Management Journal, Vol.27, pp.425-445.

Williamson, O. (1984), 'Corporate Governance', Yale Law Journal, Vol.3, pp.1197-1229.

Wooldridge, J. (2001), Econometric Analysis of Cross-section and Panel Data (MIT Press).

Useem, M. (1984), The Inner Circle: Large Corporations and the Rise of Business Political Activity (New York: Oxford University Press).

Uzzi, B. (1997), 'Social Structure and Competition in Interfirm Networks: The Paradox of Embeddedness', Administrative Science Quarterly, Vol.42, pp.35-67.

Westphal J.D. (1999), 'Collaboration in the Boardroom: Behavioral and Performance Consequences of CEO-board Social Ties', The Academy of Management Journal, Vol.42, pp.7-24.

Yermack, D. (1996), 'Higher Market Valuation of Companies with a Small Board of Directors', Journal of Financial Economics, Vol.40, pp.185-212.

Zahra, S. and Pearce, J. (1989), 'Boards of Directors and Corporate Financial Performance: A Review and Integrative Model', Journal of Management, Vol.15, pp.291-244. 


\section{Table 1}

The number of companies, directors, and observations used in constructing the network measures and the number of companies, directors and observation used in the final analysis. In addition the statistics for the final company sample. Firm closeness is the sum of the firm's executive and outside director's individual closeness. Closeness is our measure of how long it will take information to spread from a given vertex to other reachable vertices in the network. The measure is normalized and ranges from zero to one. Firm brokerage position is the sum of the firm's executive and outside director's individual brokerage position. We measure brokerage position by using the dyadic constraint which we minus from one. The dyadic constraint measures the redundancy of a director's ties. The measure is normalized and ranges from zero to one. A higher closeness and brokerage position indicates a better-networked firm. Stock return is the stock price return over one fiscal year. Sales growth is the growth in sales over one fiscal year. ROA is net income over total assets. MTB is market value of equity over book value of equity at fiscal year end.

\begin{tabular}{lccccc}
\hline Measure & $\begin{array}{c}\text { Unique } \\
\text { companies }\end{array}$ & $\begin{array}{c}\text { Unique } \\
\text { directors }\end{array}$ & $\begin{array}{c}\text { Director- } \\
\text { firm-year }\end{array}$ \\
\hline Network measures & 4,278 & 31,495 & & 111,114 \\
Excluding missing or zero compensation & $\underline{946}$ & $\underline{9,525}$ & $\underline{34,873}$ & & \\
Analysis sample & $\underline{3,332}$ & $\underline{21,970}$ & $\underline{76,241}$ & & \\
& & & & & \\
& & Standard & & & \\
& Mean & Deviation & Q3 & Median & Q1 \\
\cline { 2 - 6 } Average firm closeness & 0.087 & 0.049 & 0.120 & 0.105 & 0.078 \\
Average firm brokerage position & 0.662 & 0.226 & 0.830 & 0.674 & 0.533 \\
Market Value of equity (E'm) & 953 & 6146 & 236 & 48 & 12 \\
Stock return & $16.0 \%$ & $82.0 \%$ & $30.0 \%$ & $3.0 \%$ & $-22.0 \%$ \\
Sales growth & $12.0 \%$ & $47.0 \%$ & $21.0 \%$ & $9.0 \%$ & $-2.0 \%$ \\
ROA & $-4.0 \%$ & $22.0 \%$ & $6.0 \%$ & $2.0 \%$ & $-3.0 \%$ \\
MTB & 2.51 & 5.44 & 2.68 & 1.35 & 0.86 \\
\% Outsider directors & $57.5 \%$ & $23.5 \%$ & $71.4 \%$ & $57.1 \%$ & $42.9 \%$ \\
$\%$ Busy directors & $12.4 \%$ & $33.0 \%$ & $0.0 \%$ & $0.0 \%$ & $0.0 \%$ \\
& & & & & \\
\hline
\end{tabular}




\section{Table 2}

Panel A: Statistics for compensation, network measures and director educational background by category of executive.

We define compensation (Comp) for each director as the sum of salary, bonus, stock options, pension benefits, and other benefits in thousands of pounds but we exclude the long-term incentive plans. Comp + LTIPs includes compensation from the long-term incentive plans. We define Closeness as the inverse of the mean geodesic distance (i.e., the shortest path) between a vertex $v$ and all other vertices reachable from it. Closeness is our measure of how long it will take information to spread from a given vertex to other reachable vertices in the network. The measure is normalized and ranges from zero to one. We measure brokerage position by using the dyadic constraint which we minus from one. The dyadic constraint measures the redundancy of a director's ties. The measure is normalized and ranges from zero to one. A higher closeness and brokerage position indicates a better-networked executive or outside director. Director tenure is the number of years the director has been sitting on the board. Busy director is a director who serves in a year on three or more boards. Gender is a dummy variable and has a value of one if the individual is a male and zero if the individual is female. Top school is a dummy variable and has the value of one if the executive attended a top university such as: Oxford, Cambridge, Harvard, LSE, LBS etc. and zero otherwise. MBA is a dummy variable and has the value of one if the executive holds a MBA qualification and zero otherwise.

\begin{tabular}{|c|c|c|c|c|c|c|}
\hline & Measure & Mean & Std. Dev & Q3 & Median & Q1 \\
\hline \multirow{9}{*}{ త્ర } & Comp (£'000) & 447 & 634 & 509 & 258 & 143 \\
\hline & Comp + LTIPs (£'000) & 577 & 969 & 589 & 262 & 140 \\
\hline & Closeness & 0.083 & 0.049 & 0.118 & 0.103 & 0.069 \\
\hline & Brokerage position & 0.649 & 0.201 & 0.783 & 0.664 & 0.537 \\
\hline & Tenure & 8.2 & 6.0 & 10.0 & 7.0 & 4.0 \\
\hline & Busy director & 0.035 & 0.184 & 0.000 & 0.000 & 0.000 \\
\hline & Gender & 0.977 & 0.151 & 1.000 & 1.000 & 1.000 \\
\hline & Top School & 0.090 & 0.286 & 0.000 & 0.000 & 0.000 \\
\hline & MBA & 0.052 & 0.223 & 0.000 & 0.000 & 0.000 \\
\hline \multirow{9}{*}{ đ닌 } & Comp (£'000) & 265 & 309 & 320 & 174 & 99 \\
\hline & Comp + LTIPs (£'000) & 361 & 506 & 393 & 190 & 102 \\
\hline & Closeness & 0.085 & 0.047 & 0.118 & 0.104 & 0.078 \\
\hline & Brokerage position & 0.648 & 0.181 & 0.769 & 0.665 & 0.547 \\
\hline & Tenure & 6.3 & 4.5 & 8.0 & 5.0 & 3.0 \\
\hline & Busy director & 0.014 & 0.119 & 0.000 & 0.000 & 0.000 \\
\hline & Gender & 0.948 & 0.222 & 1.000 & 1.000 & 1.000 \\
\hline & Top School & 0.069 & 0.253 & 0.000 & 0.000 & 0.000 \\
\hline & MBA & 0.035 & 0.184 & 0.000 & 0.000 & 0.000 \\
\hline \multirow{9}{*}{ 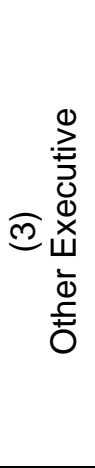 } & Comp ( $\left.£^{\prime} 000\right)$ & 352 & 520 & 412 & 205 & 109 \\
\hline & Comp + LTIPs (£'000) & 442 & 616 & 515 & 216 & 106 \\
\hline & Closeness & 0.091 & 0.047 & 0.122 & 0.108 & 0.087 \\
\hline & Brokerage position & 0.710 & 0.165 & 0.823 & 0.729 & 0.618 \\
\hline & Tenure & 6.5 & 4.4 & 8.0 & 5.0 & 3.0 \\
\hline & Busy director & 0.018 & 0.135 & 0.000 & 0.000 & 0.000 \\
\hline & Gender & 0.949 & 0.221 & 1.000 & 1.000 & 1.000 \\
\hline & Top School & 0.069 & 0.254 & 0.000 & 0.000 & 0.000 \\
\hline & MBA & 0.055 & 0.228 & 0.000 & 0.000 & 0.000 \\
\hline
\end{tabular}




\section{Table 2}

Panel B: Statistics for compensation, network measures and director educational background by category of outside director.

We define compensation for each director as the sum of salary, bonus, stock options, pension benefits, and other benefits in thousands of pounds but we exclude the long-term incentive plans. Compensation plus LTIPs includes compensation from the long-term incentive plans. We define Closeness as the inverse of the mean geodesic distance (i.e., the shortest path) between a vertex $v$ and all other vertices reachable from it. Closeness is our measure of how long it will take information to spread from a given vertex to other reachable vertices in the network. The measure is normalized and ranges from zero to one. We measure brokerage position by using the dyadic constraint which we minus from one. The dyadic constraint measures the redundancy of a director's ties. The measure is normalized and ranges from zero to one. A higher closeness and brokerage position indicates a better-networked executive or outside director. Director tenure is the number of years the director has been sitting on the board. Busy director is a director who serves in a year on three or more boards. Gender is a dummy variable and has a value of one if the individual is a male and zero if the individual is female. Top school is a dummy variable and has the value of one if the executive attended a top university such as: Oxford, Cambridge, Harvard, LSE, LBS etc. and zero otherwise. MBA is a dummy variable and has the value of one if the executive holds a MBA qualification and zero otherwise.

\begin{tabular}{|c|c|c|c|c|c|c|}
\hline & Measure & Mean & Std. Dev & Q3 & Median & Q1 \\
\hline \multirow{9}{*}{ 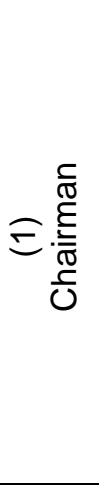 } & Comp ( $\left.£^{\prime} 000\right)$ & 102 & 170 & 109 & 40 & 20 \\
\hline & Comp + LTIPs ( $\left.£^{\prime} 000\right)$ & 88 & 127 & 100 & 40 & 19 \\
\hline & Closeness & 0.094 & 0.049 & 0.126 & 0.111 & 0.088 \\
\hline & Brokerage position & 0.755 & 0.241 & 0.953 & 0.819 & 0.600 \\
\hline & Tenure & 8.2 & 6.3 & 10.0 & 7.0 & 4.0 \\
\hline & Busy director & 0.309 & 0.462 & 1.000 & 0.000 & 0.000 \\
\hline & Gender & 0.985 & 0.121 & 1.000 & 1.000 & 1.000 \\
\hline & Top School & 0.026 & 0.159 & 0.000 & 0.000 & 0.000 \\
\hline & MBA & 0.007 & 0.084 & 0.000 & 0.000 & 0.000 \\
\hline \multirow{9}{*}{ 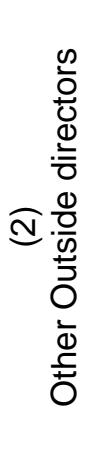 } & Comp (£'000) & 36 & 52 & 36 & 23 & 13 \\
\hline & Comp + LTIPs (£'000) & 32 & 38 & 35 & 22 & 13 \\
\hline & Closeness & 0.100 & 0.044 & 0.127 & 0.114 & 0.096 \\
\hline & Brokerage position & 0.769 & 0.208 & 0.941 & 0.803 & 0.632 \\
\hline & Tenure & 6.4 & 4.7 & 8.0 & 5.0 & 3.0 \\
\hline & Busy director & 0.227 & 0.419 & 0.000 & 0.000 & 0.000 \\
\hline & Gender & 0.933 & 0.251 & 1.000 & 1.000 & 1.000 \\
\hline & Top School & 0.021 & 0.142 & 0.000 & 0.000 & 0.000 \\
\hline & MBA & 0.010 & 0.098 & 0.000 & 0.000 & 0.000 \\
\hline
\end{tabular}


Table 3

Panel A: Correlation coefficients for the CEO (below diagonal) and other executive directors (above diagonal).

We define comp (compensation) for each director as the sum of salary, bonus, stock options, pension benefits, and other benefits in thousands of pounds but we exclude the long-term incentive plans. Comp plus LTIPs includes compensation plus long-term incentive plans. We define Closeness as the inverse of the mean geodesic distance (i.e., the shortest path) between a vertex $v$ and all other vertices reachable from it. Closeness is our measure of how long it will take information to spread from a given vertex to other reachable vertices in the network. The measure is normalized and ranges from zero to one. We measure brokerage position by using the dyadic constraint which we minus from one. The dyadic constraint measures the redundancy of a director's ties. The measure is normalized and ranges from zero to one. A higher closeness and brokerage position indicates a better-networked executive or outside director. Firm size is the log of the firm's market value of equity. Stock return is the stock price return over one fiscal year. Sales growth is the growth in sales over one fiscal year. ROA is net income over total assets. MTB is market value of equity over book value of equity at fiscal year end. Director tenure is the number of years the director has been sitting on the board. Busy director is a director who serves in a year on three or more boards. Top school is a dummy variable and has the value of one if the executive attended a top university such as: Oxford, Cambridge, Harvard, LSE, LBS etc. and zero otherwise. MBA is a dummy variable and has the value of one if the executive holds a MBA qualification and zero otherwise.

\begin{tabular}{|c|c|c|c|c|c|c|c|c|c|c|c|c|c|c|}
\hline \multirow{15}{*}{$\begin{array}{l}0 \\
0 \\
\text { ก } \\
0\end{array}$} & & \multicolumn{13}{|c|}{ Other Executive Directors } \\
\hline & Variable & Comp & $\begin{array}{c}\text { Comp } \\
+ \\
\text { LTIPs }\end{array}$ & Closeness & $\begin{array}{c}\text { Brokerage } \\
\text { position }\end{array}$ & $\begin{array}{l}\text { Firm } \\
\text { size }\end{array}$ & $\begin{array}{l}\text { Stock } \\
\text { return }\end{array}$ & $\begin{array}{c}\text { Sales } \\
\text { growth }\end{array}$ & ROA & MTB & $\begin{array}{c}\text { Director } \\
\text { tenure }\end{array}$ & $\begin{array}{c}\text { Busy } \\
\text { director }\end{array}$ & $\begin{array}{c}\text { Top } \\
\text { School }\end{array}$ & MBA \\
\hline & Comp & & 0.962 & 0.356 & 0.456 & 0.658 & -0.034 & -0.065 & 0.281 & 0.022 & 0.155 & -0.073 & 0.180 & 0.153 \\
\hline & Comp+ LTIPs & 0.960 & & 0.353 & 0.429 & 0.660 & -0.014 & -0.038 & 0.258 & 0.031 & 0.040 & -0.083 & 0.198 & 0.165 \\
\hline & Closeness & 0.385 & 0.392 & & 0.645 & 0.504 & 0.004 & -0.023 & 0.160 & 0.052 & -0.036 & 0.093 & 0.150 & 0.113 \\
\hline & Brokerage position & 0.480 & 0.480 & 0.649 & & 0.684 & -0.006 & -0.041 & 0.235 & 0.043 & -0.024 & 0.222 & 0.203 & 0.151 \\
\hline & Firm size & 0.714 & 0.733 & 0.489 & 0.639 & & 0.047 & -0.038 & 0.362 & 0.094 & -0.018 & 0.022 & 0.242 & 0.193 \\
\hline & Stock return & -0.012 & 0.019 & -0.015 & -0.007 & 0.069 & & 0.082 & 0.020 & 0.099 & -0.020 & 0.029 & 0.001 & -0.001 \\
\hline & Sales growth & -0.030 & -0.023 & -0.016 & -0.023 & -0.012 & 0.071 & & -0.038 & 0.044 & -0.082 & 0.008 & -0.004 & -0.013 \\
\hline & ROA & 0.276 & 0.244 & 0.140 & 0.203 & 0.348 & 0.030 & -0.018 & & -0.063 & 0.113 & -0.023 & 0.065 & 0.049 \\
\hline & МTB & 0.048 & 0.070 & 0.055 & 0.059 & 0.125 & 0.096 & 0.032 & -0.047 & & -0.004 & 0.018 & -0.008 & -0.009 \\
\hline & Director tenure & 0.207 & 0.124 & 0.005 & 0.080 & 0.093 & -0.030 & -0.074 & 0.195 & -0.013 & & 0.054 & 0.007 & -0.044 \\
\hline & Busy director & -0.024 & -0.024 & 0.112 & 0.272 & 0.038 & -0.012 & 0.000 & 0.006 & 0.003 & 0.081 & & 0.032 & -0.001 \\
\hline & Top school & 0.215 & 0.242 & 0.184 & 0.238 & 0.268 & -0.027 & -0.026 & 0.075 & 0.012 & 0.003 & 0.054 & & 0.210 \\
\hline & MBA & 0.135 & 0.136 & 0.116 & 0.140 & 0.169 & -0.018 & -0.038 & 0.040 & 0.030 & -0.031 & -0.004 & 0.206 & \\
\hline
\end{tabular}


Table 3

Panel B: Correlation coefficients for the independent chairman (below diagonal) and other outside directors (above diagonal).

We define comp (compensation) for each director as the sum of salary, bonus, stock options, pension benefits, and other benefits in thousands of pounds but we exclude the long-term incentive plans. Comp plus LTIPs includes compensation plus long-term incentive plans. We define Closeness as the inverse of the mean geodesic distance (i.e., the shortest path) between a vertex $v$ and all other vertices reachable from it. Closeness is our measure of how long it will take information to spread from a given vertex to other reachable vertices in the network. The measure is normalized and ranges from zero to one. We measure brokerage position by using the dyadic constraint which we minus from one. The dyadic constraint measures the redundancy of a director's ties. The measure is normalized and ranges from zero to one. A higher closeness and brokerage position indicates a better-networked executive or outside director. Firm size is the log of the firm's market value of equity. Stock return is the stock price return over one fiscal year. Sales growth is the growth in sales over one fiscal year. ROA is net income over total assets. MTB is market value of equity over book value of equity at fiscal year end. Director tenure is the number of years the director has been sitting on the board. Busy director is a director who serves in a year on three or more boards. Top school is a dummy variable and has the value of one if the executive attended a top university such as: Oxford, Cambridge, Harvard, LSE, LBS Imperial, UCL. and zero otherwise. MBA is a dummy variable and has the value of one if the executive holds a MBA qualification and zero otherwise.

\begin{tabular}{|c|c|c|c|c|c|c|c|c|c|c|c|c|c|c|}
\hline & & & & & & & Outsic & le direct & & & & & & \\
\hline & Variable & Comp & $\begin{array}{c}\text { Comp + } \\
\text { LTIPs }\end{array}$ & Closeness & $\begin{array}{c}\text { Brokerage } \\
\text { position }\end{array}$ & $\begin{array}{l}\text { Firm } \\
\text { size }\end{array}$ & $\begin{array}{l}\text { Stock } \\
\text { return }\end{array}$ & $\begin{array}{l}\text { Sales } \\
\text { growth }\end{array}$ & ROA & MTB & $\begin{array}{c}\text { Director } \\
\text { tenure }\end{array}$ & $\begin{array}{l}\text { Busy } \\
\text { director }\end{array}$ & $\begin{array}{c}\text { Top } \\
\text { School }\end{array}$ & MBA \\
\hline & Comp & & 0.997 & 0.085 & 0.180 & 0.429 & -0.004 & 0.024 & 0.090 & 0.060 & 0.119 & -0.092 & 0.048 & 0.045 \\
\hline & Comp+ LTIPs & 0.998 & & 0.096 & 0.207 & 0.462 & 0.001 & 0.022 & 0.088 & 0.071 & 0.136 & -0.078 & 0.035 & 0.037 \\
\hline & Closeness & 0.080 & 0.065 & & 0.663 & 0.400 & -0.037 & -0.050 & 0.148 & 0.014 & -0.028 & 0.319 & 0.082 & 0.041 \\
\hline & Brokerage position & 0.148 & 0.154 & 0.700 & & 0.475 & -0.024 & -0.026 & 0.150 & 0.038 & -0.043 & 0.518 & 0.120 & 0.062 \\
\hline & Firm size & 0.545 & 0.553 & 0.376 & 0.401 & & 0.068 & 0.028 & 0.293 & 0.138 & -0.075 & 0.005 & 0.104 & 0.064 \\
\hline$\frac{\rho}{2}$ & Stock return & -0.004 & 0.000 & -0.023 & -0.007 & 0.096 & & 0.100 & 0.025 & 0.081 & -0.045 & -0.016 & 0.001 & -0.007 \\
\hline$\stackrel{\infty}{3}$ & Sales growth & 0.022 & 0.028 & -0.059 & -0.025 & 0.036 & 0.086 & & -0.014 & 0.038 & -0.073 & -0.023 & -0.002 & -0.001 \\
\hline$\stackrel{\vec{g}}{丂}$ & $\mathrm{ROA}$ & 0.117 & 0.112 & 0.165 & 0.142 & 0.316 & 0.044 & -0.010 & & -0.044 & 0.065 & 0.035 & 0.017 & -0.007 \\
\hline & МТВ & 0.068 & 0.085 & 0.007 & 0.044 & 0.117 & 0.094 & 0.041 & -0.071 & & -0.045 & -0.026 & 0.012 & 0.013 \\
\hline & Director tenure & 0.164 & 0.127 & -0.015 & -0.054 & 0.074 & -0.042 & -0.079 & 0.153 & -0.038 & & 0.003 & -0.030 & -0.021 \\
\hline & Busy director & -0.150 & -0.149 & 0.397 & 0.568 & 0.001 & -0.018 & -0.029 & 0.033 & -0.013 & -0.067 & & 0.037 & 0.006 \\
\hline & Top school & 0.115 & 0.070 & 0.107 & 0.119 & 0.128 & -0.009 & 0.010 & 0.014 & 0.029 & 0.012 & 0.053 & & 0.243 \\
\hline & MBA & 0.050 & 0.053 & 0.029 & 0.033 & 0.059 & -0.014 & -0.001 & 0.008 & 0.028 & 0.002 & -0.018 & 0.209 & \\
\hline
\end{tabular}


Table 4

Panel A: Association between compensation and connectedness for CEOs, CFOs and all other executive officers.

The Table presents OLS tests in which the dependent variable is log of compensation. We define comp (compensation) for each director as the sum of salary, bonus, stock options, pension benefits, and other benefits in thousands of pounds but we exclude the long-term incentive plans.

Comp plus LTIPs includes compensation plus the long-term incentive plans. We define Closeness as the inverse of the mean geodesic distance (i.e., the shortest path) between a vertex $v$ and all other vertices reachable from it. Closeness is our measure of how long it will take information to spread from a given vertex to other reachable vertices in the network. The measure is normalized and ranges from zero to one. We measure brokerage position by using the dyadic constraint which we minus from one. The dyadic constraint measures the redundancy of a director's ties.

The measure is normalized and ranges from zero to one. A higher closeness and brokerage position indicates a better-networked executive or outside director. Gender is a dummy variable and has a value of one if the individual is a male and zero if the individual is female. Busy director is a director who serves in a year on three or more boards. Standard errors are robust to heteroskedasticity and clustered at the director level. We tabulate $t$-statistics below the coefficients in parentheses. * Significant at the $10 \%$ level, ${ }^{* *}$ Significant at $5 \%$ level, $* * *$ Significant at $0.1 \%$ level.

\begin{tabular}{|c|c|c|c|c|c|c|c|c|c|c|}
\hline & \multicolumn{4}{|c|}{ CEO } & \multicolumn{2}{|c|}{ CFO } & \multicolumn{4}{|c|}{ Other Executives } \\
\hline & (1) & (2) & (3) & $(4)$ & (5) & (6) & (7) & $(8)$ & $(9)$ & $(10)$ \\
\hline & & & Comp & Comp & & & & & Comp & Comp \\
\hline & Comp & Comp & +LTIPS & +LTIPS & Comp & Comp & Comp & Comp & +LTIPs & +LTIPS \\
\hline Intercept & 4.28 & 4.21 & 4.27 & 4.17 & 3.87 & 3.79 & 4.63 & 4.69 & 5.44 & 5.61 \\
\hline & $(8.60)^{\star \star \star}$ & $(8.22)^{\star \star \star}$ & $(4.42)^{\star \star \star}$ & $(4.16)^{\star \star \star}$ & $(11.70)^{\star \star \star}$ & $(11.13)^{\star \star \star}$ & $(11.98)^{\star \star \star}$ & $(11.85)^{\star \star \star}$ & $(10.91)^{\star \star \star}$ & $(10.82)^{\star \star \star}$ \\
\hline Closeness & $\begin{array}{l}1.11 \\
(4.19)^{\star * *}\end{array}$ & & $\begin{array}{l}1.34 \\
(3.41)^{\star \star \star}\end{array}$ & & $\begin{array}{l}1.03 \\
(4.24)^{\star \star \star}\end{array}$ & & $\begin{array}{l}0.87 \\
(2.61)^{\star \star \star}\end{array}$ & & $\begin{array}{l}1.05 \\
(2.18)^{\star \star}\end{array}$ & \\
\hline Brokerage position & & $\begin{array}{l}0.22 \\
(2.46)^{\star *}\end{array}$ & & $\begin{array}{c}0.23 \\
(1.66)^{*}\end{array}$ & & $\begin{array}{l}0.20 \\
(2.17)^{\star *}\end{array}$ & & $\begin{array}{c}-0.02 \\
(-0.13)\end{array}$ & & $\begin{array}{c}-0.22 \\
(-1.12)\end{array}$ \\
\hline Gender & $\begin{array}{c}0.09 \\
(0.95)\end{array}$ & $\begin{array}{c}0.10 \\
(0.96)\end{array}$ & $\begin{array}{c}0.09 \\
(0.54)\end{array}$ & $\begin{array}{c}0.10 \\
(0.57)\end{array}$ & $\begin{array}{c}0.07 \\
(1.37)\end{array}$ & $\begin{array}{c}0.07 \\
(1.34)\end{array}$ & $\begin{array}{l}0.15 \\
(3.29)^{\star \star \star}\end{array}$ & $\begin{array}{l}0.15 \\
(3.31)^{\star \star \star}\end{array}$ & $\begin{array}{l}0.18 \\
(2.39)^{\star \star \star}\end{array}$ & $\begin{array}{l}0.18 \\
(2.44)^{\star \star \star}\end{array}$ \\
\hline Busy director & $\begin{array}{l}-0.30 \\
(-3.61)^{\star \star \star}\end{array}$ & $\begin{array}{l}-0.33 \\
(-3.99)^{\star \star \star}\end{array}$ & $\begin{array}{l}-0.39 \\
(-3.29)^{\star \star \star}\end{array}$ & $\begin{array}{l}-0.42 \\
(-3.55)^{\star \star \star}\end{array}$ & $\begin{array}{l}-0.34 \\
(-2.46)^{\star \star}\end{array}$ & $\begin{array}{l}-0.37 \\
(-2.65)^{\star \star \star}\end{array}$ & $\begin{array}{l}-0.44 \\
(-3.35)^{\star \star \star}\end{array}$ & $\begin{array}{l}-0.40 \\
(-3.09)^{\star \star \star}\end{array}$ & $\begin{array}{l}-0.55 \\
(-3.20)^{\star \star \star}\end{array}$ & $\begin{array}{l}-0.46 \\
(-2.64)^{\star \star \star}\end{array}$ \\
\hline Human capital controls & Yes & Yes & Yes & Yes & Yes & Yes & Yes & Yes & Yes & Yes \\
\hline Job role fixed effects & No & No & No & No & No & No & Yes & Yes & Yes & Yes \\
\hline Committee fixed effects & Yes & Yes & Yes & Yes & Yes & Yes & Yes & Yes & Yes & Yes \\
\hline Firm controls & Yes & Yes & Yes & Yes & Yes & Yes & Yes & Yes & Yes & Yes \\
\hline Index fixed effects & Yes & Yes & Yes & Yes & Yes & Yes & Yes & Yes & Yes & Yes \\
\hline Year fixed effects & Yes & Yes & Yes & Yes & Yes & Yes & Yes & Yes & Yes & Yes \\
\hline Adj-R squared & $59.2 \%$ & $59.1 \%$ & $61.2 \%$ & $61.1 \%$ & $60.4 \%$ & $60.3 \%$ & $59.8 \%$ & $59.7 \%$ & $60.6 \%$ & $60.6 \%$ \\
\hline Number of observations & 9503 & 9503 & 4656 & 4656 & 7714 & 7714 & 10091 & 10091 & 5201 & 5201 \\
\hline Number of individuals & 3650 & 3650 & 2412 & 2412 & 3000 & 3000 & 4300 & 4300 & 2756 & 2756 \\
\hline Number of firms & 2393 & 2393 & 1741 & 1741 & 2119 & 2119 & 1717 & 1717 & 1245 & 1245 \\
\hline
\end{tabular}


Table 4

Panel B: Association between compensation and connectedness for chairman and all other outside directors.

The Table presents OLS test in which the dependent variable is compensation. We define comp (compensation) for each director as the sum of salary, bonus, stock options, pension benefits, and other benefits in thousands of pounds but we exclude the long-term incentive plans. Comp plus LTIPs includes compensation plus the long-term incentive plans. We define Closeness as the inverse of the mean geodesic distance (i.e., the shortest path) between a vertex $v$ and all other vertices reachable from it. Closeness is our measure of how long it will take information to spread from a given vertex to other reachable vertices in the network. The measure is normalized and ranges from zero to one. We measure brokerage position by using the dyadic constraint which we minus from one. The dyadic constraint measures the redundancy of a director's ties. The measure is normalized and ranges from zero to one. A higher closeness and brokerage position indicates a better-networked executive or outside director. Gender is a dummy variable and has a value of one if the individual is a male and zero if the individual is female. Busy director is a director who serves in a year on three or more boards. Standard errors are robust to heteroskedasticity and clustered at the director level. We

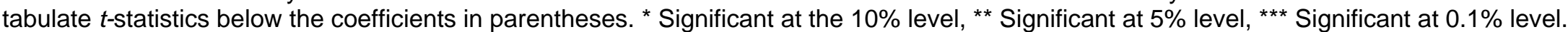

\begin{tabular}{|c|c|c|c|c|c|c|c|c|}
\hline & \multicolumn{4}{|c|}{ Chairman } & \multicolumn{4}{|c|}{ All other outside directors } \\
\hline & (1) & $(2)$ & $(3)$ & $(4)$ & (5) & $(6)$ & $(7)$ & $(8)$ \\
\hline & Comp & Comp & Comp+LTIPs & Comp+LTIPs & Comp & Comp & Comp+LTIPs & Comp+LTIPs \\
\hline Intercept & 3.69 & 3.66 & 3.60 & 3.58 & 2.75 & 2.66 & 2.62 & 2.50 \\
\hline & $(8.62)^{\star \star \star}$ & $(8.65)^{\star \star \star}$ & $(7.28)^{\star \star \star}$ & $(7.34)^{\star \star \star}$ & $(16.01)^{\star \star \star}$ & $(14.98)^{\star \star \star}$ & $(11.18)^{\star \star \star}$ & $(10.45)^{\star \star \star}$ \\
\hline Closeness & $\begin{array}{l}0.71 \\
(2.18)^{\star \star}\end{array}$ & & $\begin{array}{c}0.60 \\
(1.64)^{*}\end{array}$ & & $\begin{array}{c}0.95 \\
(3.45)^{\star \star \star \star}\end{array}$ & & $\begin{array}{l}0.81 \\
(2.66)^{\star \star \star}\end{array}$ & \\
\hline Brokerage position & & $\begin{array}{l}0.22 \\
(2.53)^{\star \star}\end{array}$ & & $\begin{array}{l}0.20 \\
(2.33)^{\star \star}\end{array}$ & & $\begin{array}{l}0.26 \\
(3.43)^{\star \star \star}\end{array}$ & & $\begin{array}{l}0.30 \\
(3.51)^{\star \star \star}\end{array}$ \\
\hline & $(1.81)^{\star}$ & $(1.69)^{\star}$ & $(2.11)^{\star \star}$ & $(2.04)^{\star \star}$ & $(2.91)^{\star \star}$ & $(2.81)^{\star \star}$ & $(2.53)^{\star \star}$ & $(2.43)^{\star \star}$ \\
\hline Busy director & -0.17 & -0.21 & -0.12 & -0.16 & -0.07 & -0.12 & -0.04 & -0.09 \\
\hline & $(-6.37)^{\star \star \star}$ & $(-6.13)^{\star \star \star}$ & $(-4.65)^{\star \star \star}$ & $(-5.06)^{\star \star \star}$ & $(-5.18)^{\star \star \star}$ & $(-4.65)^{\star \star \star}$ & $(-2.63)^{\star \star}$ & $(-3.45)^{\star \star \star}$ \\
\hline Human capital controls & Yes & Yes & Yes & Yes & Yes & Yes & Yes & Yes \\
\hline Job role fixed effects & No & No & No & No & Yes & Yes & Yes & Yes \\
\hline Committee fixed effects & Yes & Yes & Yes & Yes & Yes & Yes & Yes & Yes \\
\hline Firm controls & Yes & Yes & Yes & Yes & Yes & Yes & Yes & Yes \\
\hline Year fixed effects & Yes & Yes & Yes & Yes & Yes & Yes & Yes & Yes \\
\hline Adj-R squared & $55.2 \%$ & $55.2 \%$ & $55.5 \%$ & $55.5 \%$ & $36.8 \%$ & $36.9 \%$ & $38.8 \%$ & $38.9 \%$ \\
\hline Number of observations & 11429 & 11429 & 8623 & 8623 & 37504 & 37504 & 31553 & 31553 \\
\hline Number of individuals & 3548 & 3548 & 3164 & 3164 & 11684 & 11684 & 10765 & 10765 \\
\hline Number of firms & 3072 & 3072 & 2808 & 2808 & 3197 & 3197 & 3085 & 3085 \\
\hline
\end{tabular}




\section{Table 5}

Association between a firm's closeness and its future performance Panel A present OLS tests in which the dependent variable is future firm performance. Average firm closeness is the sum of each firm's individual directors closeness divided by the number of directors on the board. Closeness is the inverse of the mean geodesic distance (i.e., the shortest path) between a vertex $v$ and all other vertices reachable from it. Closeness is our measure of how long it will take information to spread from a given vertex to other reachable vertices in the network. The measure is normalized and ranges from zero to one. A higher closeness indicates a better-networked firm. Market-to-book is the market value of equity over book value of equity at fiscal year end. Return-on assets is net income over total assets. Firm size is the logarithm of the market value of equity when dependent variable is stock return. We average all performance variables across the estimation or test period. Busy director is a director who serves in a year on three or more boards. Standard errors are robust to heteroskedasticity. We tabulate $t$-statistics below the coefficients in parentheses. * Significant at the $10 \%$ level, ** Significant at $5 \%$ level, ${ }^{* \star *}$ Significant at $0.1 \%$ level.

\begin{tabular}{|c|c|c|c|c|c|c|c|c|c|}
\hline \multirow[t]{2}{*}{ Dependent variables: } & \multicolumn{3}{|c|}{ Stock return } & \multicolumn{3}{|c|}{ Market-to-book (MTB) } & \multicolumn{3}{|c|}{ Return-on-assets (ROA) } \\
\hline & (1) & $(2)$ & (3) & $(4)$ & (5) & (6) & $(7)$ & $(8)$ & (9) \\
\hline & One-year & Two-year & Three-year & One-year & Two-year & Three-year & One-year & Two-year & Three-year \\
\hline \multirow[t]{2}{*}{ Intercept } & -28.76 & -6.77 & 3.77 & 0.02 & 0.32 & 0.52 & -4.33 & -3.57 & -2.09 \\
\hline & $(-9.18)^{\star \star \star}$ & $(-2.11)^{\star \star}$ & $(1.15)$ & $(-0.16)$ & $(1.90)^{\star}$ & $(2.55)^{\star \star}$ & $(-4.54)^{\star \star \star}$ & $(-3.12)^{\star \star}$ & $(-1.67)^{\star}$ \\
\hline \multirow[t]{2}{*}{ Aggregate firm closeness } & 22.14 & 46.09 & 38.12 & 1.87 & 2.60 & 3.32 & 11.76 & 17.16 & 15.13 \\
\hline & $(1.71)^{*}$ & $(3.15)^{\star \star \star}$ & $(2.62)^{\star *}$ & $(4.49)^{\star \star \star *}$ & $(4.68)^{\star \star \star}$ & $(5.03)^{\star \star \star}$ & $(3.30)^{\star * *}$ & $(3.92)^{* * *}$ & $(3.1)^{\star *}$ \\
\hline \multirow[t]{2}{*}{ Lag stock return } & 0.04 & -0.002 & 0.001 & & & & & & \\
\hline & $(3.19)^{\star \star \star}$ & $(-0.20)$ & $(0.04)$ & & & & & & \\
\hline \multirow[t]{2}{*}{ Lag market-to-book } & -2.28 & -1.94 & -1.68 & 0.56 & 0.53 & 0.56 & & & \\
\hline & $(-8.07)^{\star \star \star}$ & $(-6.88)^{\star \star \star}$ & $(-5.46)^{\star \star \star}$ & $(33.95)^{\star \star \star}$ & $(25.87)^{\star \star \star}$ & $(23.55)^{\star \star \star}$ & & & \\
\hline \multirow[t]{2}{*}{ Lag return-on-assets } & & & & & & & 0.62 & 0.54 & 0.46 \\
\hline & & & & & & & $(35.96)^{\star \star \star}$ & $(25.56)^{\star \star \star}$ & $(21.7)^{\star \star \star}$ \\
\hline \multirow[t]{2}{*}{ Firm size } & -0.38 & -0.71 & -0.60 & & & & & & \\
\hline & $(-1.2)$ & $(-2.16)^{\star \star}$ & $(-1.81)^{\star}$ & & & & & & \\
\hline \multirow[t]{2}{*}{$\%$ Outsider directors } & 4.74 & 2.67 & 2.24 & 0.05 & 0.01 & -0.86 & 2.47 & 2.92 & 2.98 \\
\hline & $(1.81)^{\star}$ & $(1.03)$ & $(0.85)$ & $(0.54)$ & $(0.10)$ & $(-0.57)$ & $(2.84)^{\star \star}$ & $(3.08)^{\star \star}$ & $(2.96)^{\star \star}$ \\
\hline \multirow[t]{2}{*}{$\%$ Busy directors } & -2.21 & -6.22 & -4.61 & -0.05 & -0.15 & -0.22 & -1.47 & -2.07 & -1.32 \\
\hline & $(-0.91)$ & $(-2.35)^{\star \star}$ & $(-1.7)^{\star}$ & $(-0.60)$ & $(-1.59)$ & $(-1.81)^{\star}$ & $(-1.87)^{\star}$ & $(-2.03)^{\star \star}$ & $(0.28)$ \\
\hline Human capital controls & Yes & Yes & Yes & Yes & Yes & Yes & Yes & Yes & Yes \\
\hline Year fixed affects & Yes & Yes & Yes & Yes & Yes & Yes & Yes & Yes & Yes \\
\hline Industry fixed effects & Yes & Yes & Yes & Yes & Yes & Yes & Yes & Yes & Yes \\
\hline $\mathrm{N}$ & 6934 & 5664 & 4457 & 7021 & 5736 & 4501 & 7240 & 5893 & 4644 \\
\hline Adj-R squared & $25.49 \%$ & $23.23 \%$ & $18.61 \%$ & $51.71 \%$ & $47.18 \%$ & $46.81 \%$ & $50.13 \%$ & $49.01 \%$ & $47.02 \%$ \\
\hline
\end{tabular}

